TRILOGI: Jurnal Penelitian Ilmu Sosial dan Eksakta Volume: 1, Nomor 1, 2021, Hal: 7-16

\title{
Pengaruh Marketing Mix Terhadap Keputusan Pembelian Snack Pada UD Vira Jember
}

\author{
Fitra Fidianti Ningsih*, Akhmad Suharto dan Yohanes Gunawan Wibowo \\ Universitas Muhammadiyah Jember; fitrafidiantiningsih@gmail.com, akhmadsuharto@unmuhjember.ac.id, \\ gunawanwibowo@unmuhjember.ac.id
}

\begin{abstract}
Abstrak: Bauran pemasaran atau lebih dikenal dengan marketing mix merupakan strategi yang memiliki dampak pada keputusan pembilan suatu produk. Tujuan penelitian ini adalah untuk mengevaluasi dan menguji pengaruh dari marketing mix yaitu produk,harga,promosi dan lokasi/saluran distribusi terhadap keputusan pembelian pada UD Vira Jember. Penelitian semacam ini menyelidiki hubungan antara sebab dan akibat. Konsumen atau pembeli barang-barang UD Vira Jember membentuk populasi studi, sebanyak 80 orang dimasukkan dalam sampel. Beberapa regresi linear digunakan dalam perangkat lunak analisis. Hasil penelitian membuktikan bahwa marketing mix berpengaruh positif terhadap keputusan pembelian, jadi dapat ditarik kesimpulan bahwa jika produk, harga, DOI: https://doi.org/10.47134/trilogi.v1i1.3 *Correspondensi: Fitra Fidianti Ningsih promosi, dan lokasi/saluran distribusi dikembangkan lebih baik lagi maka akan meningkatkan keputusan pembelian pada UD Vira Jember.
\end{abstract} Email: fitrafidiantiningsih@gmail.com

Kata kunci: Marketing Mix, Keputusan Pembelian

Received: 21 Juli 2021

Accepted: 28 Juli 2021

Published: 30 September 2021

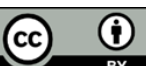

Copyright: (C) 2021 by the authors. Submitted for possible open access publication under the terms and conditions of the Creative Commons Attribution (CC BY) license (http://creativecommons.org/licenses/by/4 $.0 /)$.

\begin{abstract}
Abstrak: The marketing mix or better known as the marketing mix is a strategy that has an impact on purchasing decisions for a product. The purpose of this study is to evaluate and test the influence of marketing mix, namely products, prices, promotions and distribution locations / channels on purchasing decisions at UD Vira Jember. This kind of research investigates the relationship between cause and effect. Consumers or buyers of UD Vira Jember goods form a study population, as many as 80 people were included in the sample. Some linear regressions are used in analysis software. The results prove that marketing mix has a positive influence on purchasing decisions, so it can be concluded that if the product, price, promotion, and location I distribution channel is developed better then it will increase the purchase decision on UD Vira Jember.
\end{abstract}

Keywords: Marketing Mix, Purchasing Decisions

\section{Pendahuluan}

Perkembangan bisnis industri di Indonesia saat ini memang sedang mengalami perkembangan diberbagai sektor, salah satunya yaitu pada sektor industri makanan dan minuman, menurut Kemenperin bisnis makanan dan minuman naik sebesar 0,22 persen secara tahunan pada kuartal II-2020 (Biro Pusat Statistik). Pada persaingan dunia ndustri ini Fenomena bauran pemasaran menjadi faktor penting yang harus diperhatikan bagi setiap perusahaan agar mampu bersaing di pasar. Bauran pemasaran atau lebih dikenal dengan marketing mix merupakan strategi yang memiliki dampak pada keputusan pembilan suatu produk. (Kotler, 2009) menyatakan bahwa marketing mix atau bauran pemasaran adalah suatu seperangkat atau alat pemasaran yang di gunakan oleh suatu perusahaan untuk mencapai tujuan pemasarannya. Dalam marketing mix terdapat 4P yaitu product, price, pleace, promotion. 
Dalam industri sektor makanan dan minuman yang berkembang ini banyak sekali macamnya salah satunya di kota Jember. Seiring berjalannya waktu di kota Jember banyak bermunculan usaha industri makanan salah satunya industri makanan snack yaitu UD Vira Jember. UD Vira Jember adalah salah satu industri makanan yang menjual berbagai macam snack, pada UD Vira ini saat ini sedang mengalami jumlah penjualan yang naik turunya yang dipengaruhi oleh beberapa faktor, hal ini dapat di lihat pada tabel 1.

Tabel 1. Data Penjualan UD Vira Jember Tahun 2020

\begin{tabular}{lll}
\hline \multicolumn{1}{c}{ Bulan } & Target Penjualan & \multicolumn{1}{c}{ Realisasi } \\
\hline Januari & IDR. 300.000.000 & IDR. 377.322.000 \\
\hline Februari & IDR. 300.000.000 & IDR. 344.450.000 \\
\hline Maret & IDR. 300.000.000 & IDR. 160.740.000 \\
\hline April & IDR. 300.000.000 & IDR. 130.760 .000 \\
\hline Mei & IDR. 300.000.000 & IDR. 136.850.000 \\
\hline Juni & IDR. 300.000.000 & IDR. 240.980.000 \\
\hline Juli & IDR. 300.000.000 & IDR. 290.670.000 \\
\hline Agustus & IDR. 300.000.000 & IDR. 366.201.000 \\
\hline September & IDR. 300.000.000 & IDR. 355.444.000 \\
\hline Oktober & IDR. 300.000.000 & IDR. 317.430.000 \\
\hline \multicolumn{1}{c}{ Total } & IDR. 3.600.000.000 & IDR. 2.720.847.000 \\
\hline
\end{tabular}

Sumber : Data Diolah, April (2021)

Dapat dilihat dari tabel 1 bahwa jumlah pengunjung yang melakukan pembelian produk di UD Vira Jember pada bulan Januari hingga bulan Oktober cukup banyak dan terkadang melebihi target penjualannya, namun ada beberapa bulan yang mengalami fluktuasi dalam penjualannya, hal tersebut bisa dilihat dari data penjualan UD Vira Jember bulan Maret hingga Bulan Mei tahun 2020. Dengan adanya staretgi marketing mix diharapkan mampu meningkatkan keputusan pembelian konsumen sehingga mampu meningkatkan hasil penjualan UD Vira Jember.

Pada penelitian dilakukan oleh (Ulus, 2013) menemukan beberapa variabel pada marketing mix berpengaruh terhadap keputusan pembelian baik dari produk, harga tempat dan promosi. Sehingga H1 yaitu Produk (X1) diduga memiliki dampak besar pada keputusan untuk membeli di UD Vira Jember. Temuan penelitian yang dilakukan oleh (Hermawan, 2015) menumkan beberapa variabel tidak berpengaruh pada keputusan pemelian yaitu pada variabel produk, namun pada seluruh tingak pengaruh marketing mix tetap berpengaruh secara keseluruhan pada keputusan pembelian maka H2: Harga (X2) diduga memiliki dampak besar pada keputusan untuk membeli di UD Vira Jember. Pada penelitian yang dilakukan oleh (Setiawan, 2014) menyatakan bahwa seluruh variabel penelitainnya yaitu marketing mix (produk, harga, tempat dan promosi) dinyatakan berpengaruh signifikan dan positif pada keputusan pembelian, pada penelitiannya tidak 
ada gap pada penelitiannya lainnya maka, H3:Promosi (X3) diduga memiliki dampak besar pada keputusan untuk membeli di UD Vira Jember.

Pada penelitian (Firmansyah, 2015) menemukan hasil bahwa marketing mix berpengaruh pada keputusan pembelian atau dengan kata lain memiliki dampak yang cukup besar, yang ada pada objek penelitiannya yaitu pada Motor Honda di kota Surabaya, maka H4 : Tempat (X4) diduga memiliki dampak besar pada keputusan untuk membeli di UD Vira Jember. Seluruh penelitian terdahulu sejalan dengan pelitian yang akan peneliti lakukan yaitu tentang pengaruh marketing mix terhadap keputusan pembelian.

\section{Metode}

\section{Desain Penelitian}

Penelitian ini merupakan desain penelitian kausalitas, dimana kausalitas dilihat ketika variabel yang merupakan variabel bebas mengalami kendala.

\section{Definisi Operasional Variabel}

Penelitian ini akan melihat berbagai pengaruh produk, harga, promosi, dan lokasi terhadap keputusan belanja UD Vira Jember. Variabel dalam penelitian ini adalah :

1. Produk (X1) yaitu Cita rasa, Varian produk, Kualitas produk

2. Harga (X2) yaitu Harga sebanding dengan produk yang ditawarkan,Harga yang ditawarkan terjangkau, Harga bersaing dengan kompetitor.

3. Promosi (X3) yaitu Mengetahui keberadaan UD Vira Jember di media sosial, Mengetahui keberadaan UD Vira Jember karena ajakan teman dan Promosi penjualan

4. Lokasi/saluran diatribusi (X4) yaitu Saluran pemasaran, Jarak tempuh penjualan, Persedian.

\section{Populasi dan Sampel}

Populasi dalam penelitian ini yaitu konsumen produk UD Vira Jember, dengan jumlah sampel yang berjumlah 80 responden.

\section{Teknik Pengumpulan Data}

Pada penelitian ini, metode pengumpulan data yang digunakan ada 3 hal yaitu menggunakan wawancara, kuesioner dan observasi. Wawancara yang di ajukan akan langsung ditujukan pada pemiliki UD Vira Jember itu sendiri, sedangkan kuesioner akan dibagikan kepada konsumen untuk menilai tingkat keputusan pembelian pada penelitian ini, kemudian observasi akan langsung dilakukan pada tempat penelitian guna mendapatkan informasi yang valid. 
Teknik Analisis Data

Uji Instrumen Data

Uji Validitas

Uji validitas sebagai alat ukur dalam penelitian ini yaitu menggunakan korelasi produck moment pearson's, yaitu dengan cara mengkorelasikan tiap pertanyaan dengan skor total, kemudian hasil korelasi tersebut dibandingkan dengan angka kritis taraf signifikan 0,05 .

\section{Uji Reliabilitas}

Uji Reliabilitas pada penelitian ini menggunakan pengujian kendala alat ukur yaitu menggunakan reliabilitas metode alpha (a) yang digunakan adalah metode cronbach.

Analisis Regresi Linear Berganda

Dalam analisis regresi variabel, variabel yang mempengaruhi disebut sebagai variabel independen, dan variabel yang mempengaruhi disebut sebagai variabel dependen. Untuk mengetahui pengaruh produk (X1), harga (X2), promosi (X3), dan tempat (X4), terhadap keputusan pembelian digunakanlah rumusan yaitu :

$$
\mathrm{Y}=\mathrm{a}+\mathrm{b} 1 \mathrm{X} 1+\mathrm{b} 2 \mathrm{X} 2+\mathrm{b} 3 \mathrm{X} 3+\mathrm{b} 4 \mathrm{X} 4+\mathrm{e}
$$

\section{Uji Hipotesis}

Jika nilai tes statistik berada di area kunci (area di mana Ho ditolak), perhitungan statistik dianggap signifikan secara statistik; jika tidak, itu disebut tidak signifikan ketika nilai tes statistik berada di daerah di mana Ho diterima (Ghozali, 2005).

Uji Koefisien dan Determinasi $\left(\mathrm{R}^{2}\right)$

Koefisiensi determinasi (R2) dapat diperoleh suatu nilai untuk mengukur besarnya sumbangan dari beberapa variabel $\mathrm{X}$ terhadap variasi naik turunnya variabel $\mathrm{Y}$. Nilai R2 rendah menunjukkan bahwa variabel independen hanya dapat menggambarkan sejumlah kecil variabel dependen.

\section{Hasil dan Pembahasan}

Tabel 2. Hasil Uji Validitas

\begin{tabular}{cccccc}
\hline Jenis Variabel & Variabel & R tabel 5\% (80) & R Hitung & Signifikasi & Keterangan \\
& X1.1 & 0,220 & 0,837 & 0.000 & Valid \\
Produk (X1) & X1.2 & 0,220 & 0.804 & 0.000 & Valid \\
& X1.3 & 0,220 & 0,826 & 0.000 & Valid \\
Harga (X2) & X2.1 & 0,220 & 0,784 & 0.000 & Valid \\
& X2.2 & 0,220 & 0,839 & 0.000 & Valid \\
& X2.3 & 0,220 & 0,838 & 0.000 & Valid \\
& X3.1 & 0,220 & 0,749 & 0.000 & Valid
\end{tabular}




\begin{tabular}{cccccc} 
Prmosi (X3) & X3.2 & 0,220 & 0,777 & 0.000 & Valid \\
& X3.3 & 0,220 & 0,825 & 0.000 & Valid \\
Lokasi/Saluran & X4.1 & 0,220 & 0,812 & 0.000 & Valid \\
Distrubusi (X4) & X4.2 & 0,220 & 0,866 & 0.000 & Valid \\
& X4.3 & 0,220 & 0,816 & 0.000 & Valid \\
& Y1.1 & 0,220 & 0,785 & 0.000 & Valid \\
Keputusan & Y1.2 & 0,220 & 0,893 & 0.000 & Valid \\
Pembelian (Y) & Y1.3 & 0,220 & 0,818 & 0.000 & Valid \\
& Y1.4 & 0,220 & 0,702 & 0,000 & Valid \\
\hline
\end{tabular}

Sumber : Data Diolah, April (2021)

Pada tabel 1 menunjukkan bahwa semua variabel adalah valid dan konsisten, dan instrumen dalam penelitian ini dianggap valid karena $r$ estimasi lebih besar dari $r$ tabel, yaitu 0,220, dan nilai signifikansinya lebih kecil dari 0,05.

Tabel 3. Hasil Uji Reliabilitas

\begin{tabular}{cccc}
\hline Variabel & Cronbach Alpa & Reliabilitas & Keterangan \\
Produk (X1) & 0,60 & 0,758 & Reabilitas diterima \\
Harga (X2) & 0,60 & 0,756 & Reabilitas diterima \\
Promosi (X3) & 0,60 & 0,686 & Reabilitas diterima \\
Lokasi (X4) & 0,60 & 0,777 & Reabilitas diterima \\
Keputusan & 0,60 & 0,811 & Reabilitas diterima \\
Pembelian (Y) & & & \\
\hline
\end{tabular}

Sumber : Data diolah, April (2021)

Tabel 3 menunjukkan bahwa semua variabel dari uji reliabilitas memiliki nilai total lebih besar dari 0,60 (cronbach alpha) menunjukkan reliabel atau konsisten. Menurut (Ghozali, 2018), jika skor Cronbach's Alpha lebih dari 0,60, kuesioner atau kuesioner dianggap reliabel atau konsisten.

Tabel 4. Hasil Uji Multikolonieritas

\begin{tabular}{cccc}
\hline Variabel & Tolerence & VIF & Keterangan \\
Produk (X1) & 0,336 & 2,974 & Tidak Ada Multikolonieritas \\
Harga (X2) & 0,406 & 2,463 & Tidak Ada Multikolonieritas \\
Promosi (X3) & 0,420 & 2,379 & Tidak Ada Multikolonieritas \\
Lokasi/Saluran & 0,729 & 1,372 & Tidak Ada Multikolonieritas \\
Distribusi (X4) & & & \\
\hline
\end{tabular}

Sumber : Data diolah, April (2021)

Pada tabel 4 semua variabel bebas memiliki nilai toleransi lebih besar dari 0,1 dan nilai VIF kurang dari 10. Sedangkan menurut Ghozali (2018), nilai toleransi yang kurang 
dari 10 atau sama dengan nilai VIF biasanya digunakan untuk menunjukkan adanya multikolinearitas. lebih dari 0,1 Kesimpulannya adalah tidak ada multikolinearitas.

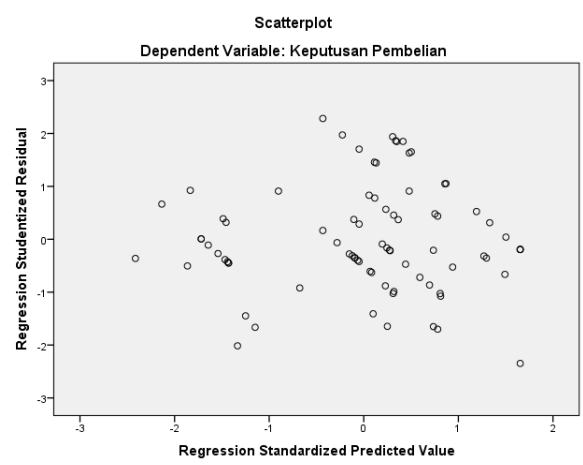

Gambar 1. Hasil Uji Heteroskedastisitas.

Sumber : Data diolah, April (2021)

Berdasarkan gambar 1 hasil uji heteroskedastisita titik-titik tersebut berada di atas dan diambil secara acak dengan angka 0 pada sumbu $Y$, seperti yang dapat dilihat. Dapat disimpulkan bahwa tidak terjadi heteroskedastisitas dalam model regresi. Hal ini sejalan dengan penegasan (Ghozali, 2018) bahwa tidak terjadi heteroskedastisitas jika tidak ada pola yang terlihat dan titik-titik tersebar di atas dan di bawah angka 0 pada sumbu $Y$.

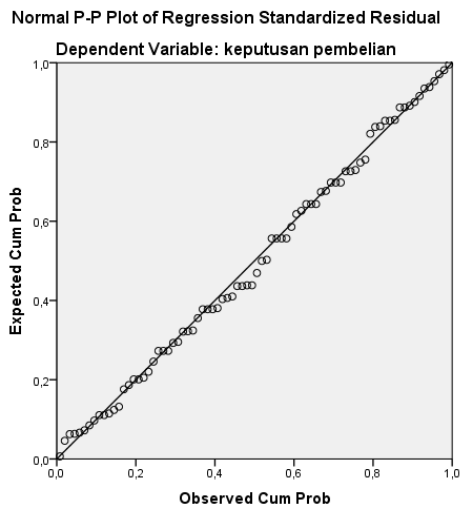

Gambar 2. Hasil Uji Normalitas

Sumber : Data diolah, April (2021)

Pada gambar 2 variabel dependen Residual Standar Y, hal ini Saat titik pada baris mengikuti garis diagonal, data dalam gambar 1 bagan dianggap didistribusikan secara teratur.

Tabel 5. Hasil Analisis Regresi Linier Berganda

\begin{tabular}{|c|c|c|c|c|c|c|}
\hline \multirow{2}{*}{\multicolumn{2}{|c|}{ Model }} & \multicolumn{2}{|c|}{$\begin{array}{l}\text { Unstandardized } \\
\text { Coefficients }\end{array}$} & \multirow{2}{*}{$\begin{array}{c}\text { Standardized } \\
\text { Coefficients } \\
\text { Beta }\end{array}$} & \multirow{3}{*}{$\begin{array}{c}\mathrm{T} \\
1,580\end{array}$} & \multirow{3}{*}{$\begin{array}{l}\text { Sig. } \\
118\end{array}$} \\
\hline & & $\mathrm{B}$ & Std. Error & & & \\
\hline \multirow[t]{3}{*}{1} & (Constant) & 2,248 & 1,423 & & & \\
\hline & Produk & ,348 & 163 & 230 & 2,135 & ,036 \\
\hline & Harga & ,383 & 144 & 260 & 2,652 & ,010 \\
\hline
\end{tabular}




\begin{tabular}{lrrrrr} 
Promosi &, 325 &, 147 & ,213 & 2,206 &, 030 \\
$\begin{array}{l}\text { Lokasi/Saluran } \\
\text { Distribusi }\end{array}$ &, 446 &, 103 &, 316 & 4,315 &, 000 \\
\hline
\end{tabular}

Sumber : Data diolah, April (2021)

Pada uji regresi pada tabel 5 penelitian ini menghasilkan persamaan regresi sebagai berikut:

$$
\mathrm{Y}=\mathbf{2 , 2 4 8}+0,348 \mathrm{X}_{1}+0,383 \mathrm{X}_{2}+0,325 \mathrm{X}_{3}+0,446 \mathrm{X}_{4}+\mathrm{e}
$$

Persamaan regresi tabel 5 dapat dijelaskan sebagai berikut:

1. $\mathrm{a}=$ Kostanta senilai 2,248 Jika variabel produk, harga, promosi, dan lokasi distribusi/saluran (marketing mix) diadakan secara konstan, maka pembelian UD Vira Jember akan berpengaruh positif sebesar 2.248..

2. Variabel produk (X1) membeli keputusan dengan koefisien positif dengan nilai 0,348. Artinya setiap penambahan variabel produk sebesar 1, maka produk akan mengalami peningkatan sebesar 0,348.

3. Variabel harga (X2) membeli keputusan dengan koefisien positif dengan nilai 0,383. Artinya setiap penambahan variabel harga sebesar 1, maka harga akan mengalami peningkatan sebesar 0,383 .

4. Variabel promosi (X3) membeli keputusan dengan koefisien positif dengan nilai 0,325. Artinya setiap penambahan variabel promosi sebesar 1, maka promosi akan mengalami peningkatan sebesar 0,325.

5. Variabel lokasi/saluran distribusi (X4) membeli keputusan dengan koefisien positif dengan nilai 0,446. arah pembelian dengan koefisien positif Ini menunjukkan bahwa menambahkan satu lagi variabel lokasi / saluran distribusi meningkatkan lokasi / saluran distribusi sebesar 0,446.

Tabel 6. Hasil Uji t

\begin{tabular}{ccc}
\hline Variabel & t hitung & Signifikasi \\
Produk $(\mathrm{X} 1)$ & 2,135 & 0,036 \\
Harga $(\mathrm{X} 2)$ & 2,652 & 0,010 \\
Promosi $(\mathrm{X} 3)$ & 2,206 & 0,030 \\
Lokasi $(\mathrm{X} 4)$ & 4,315 & 0,000 \\
\hline
\end{tabular}

Sumber : Data diolah, April (2021)

Berdasarkan tabel 6 hasil uji t pada penelitian ini dapat dijelaskan bahwa seluruh variabel di katakan berpengaruh signifikan, sesuai data semua variabel nilai signifikannya kurang atau lebih kecil dari 0,05. 
Tabel 7. Hasil Uji F

ANOVA $^{\mathrm{a}}$

\begin{tabular}{|c|c|c|c|c|c|c|}
\hline \multicolumn{2}{|c|}{ Model } & \multicolumn{5}{|l|}{ Sum of } \\
\hline 1 & Regression & 368,019 & 4 & 92,005 & 45,165 &, $000^{\mathrm{t}}$ \\
\hline & Residual & 152,781 & 75 & 2,037 & & \\
\hline & Total & 520,800 & 79 & & & \\
\hline
\end{tabular}

Sumber : Data diolah, April (2021)

Pada tabel 7 hasil uji F menghitung 45.165 dengan tingkat signifikansi 0,000, menurut temuan tes F dalam tabel di atas. Ho ditolak sementara H1 disetujui, menurut (Ghozali, 2018), dengan nilai signifikansi F 0,05. Maka dapat disimpulkan bahwa variabel independen secara serentak dan signifikansi mempengaruhi variabel dependen yakni keputusan pembelian $(\mathrm{Y})$.

Tabel 8. Hasil Koefisien Determinasi Berganda $\mathbf{R}^{2}$

Model Summary ${ }^{\mathrm{b}}$

\begin{tabular}{|c|c|c|c|c|c|}
\hline Model & $\mathrm{R}$ & R Square & $\begin{array}{l}\text { Adjusted R } \\
\text { Square }\end{array}$ & $\begin{array}{l}\text { Std. Error of } \\
\text { the Estimate }\end{array}$ & $\begin{array}{l}\text { Durbin-Wats } \\
\text { on }\end{array}$ \\
\hline 1 &, $841^{a}$ & ,707 & 691 & 1,42726 & 1,840 \\
\hline
\end{tabular}

Sumber : Data diolah, April (2021)

Menurut hasil analisis, yang dapat dilihat dalam tabel 8, koefisien penentuan ganda (R2) 0,707 menunjukkan bahwa variabel produk, harga, promosi, dan lokasi distribusi / saluran mempengaruhi 70,7 persen keputusan pembelian, sementara 48,7\% sisanya dipengaruhi oleh faktor lain.

Menurut hipotesis pertama, produk ini memiliki dampak besar pada keputusan pembelian. Penelitian ini menegaskan bahwa produk tersebut berdampak besar pada keputusan pembelian, yang konsisten dengan studi lain, seperti (Hermawan, 2015) dan (Pratiwi, 2016) mengatakan bahwa temuan studinya menunjukkan bahwa variabel independen mempengaruhi variabel dependen (keputusan pembelian) dengan cara parsial (produk). Jika produk UD Vira Jember ditingkatkan, baik dari segi varian rasa maupun varian produk, maka semakin tinggi tingkat keputusan pembelian yang akan dibuat pelanggan saat membeli atau berbelanja di UD Vira Jember. Jelas bahwa hipotesis diterima dalam penyelidikan ini.

Harga memiliki pengaruh besar pada keputusan pembelian, menurut hipotesis kedua. Harga memiliki dampak besar pada keputusan pembelian, menurut penelitian ini, yang konsisten dengan studi masa lalu yaitu (Rosmaniar, 2015) dan (Tantra, 2016) yang menyatakan bahwa harga berpengaruh signifikan terhadap keputusan pembelian. Jika harga yang diberikan UD Vira Jember ditingkatkan lebih banyak lagi, maka akan semakin besar pula tingkat keputusan pembelian yang akan dilakukan pelanggan untuk membeli 
atau berbelanja di UD Vira Jember nantinya. Jelas bahwa hipotesis diterima dalam penyelidikan ini.

Promosi memiliki dampak besar pada keputusan pembelian, menurut hipotesis ketiga. Penelitian ini menegaskan bahwa promosi memiliki dampak besar pada keputusan pembelian, yang konsisten dengan studi sebelumnya yaitu (Budiwati, 2012) dan (Wulandari, 2012) yang menyatakan bahwa promosi berpengaruh signifikan terhadap keputusan pembelian. Semakin tinggi tingkat keputusan pembelian yang akan dilakukan pelanggan saat membeli atau berbelanja di UD Vira Jember jika promosi yang diberikan UD Vira Jember semakin ditingkatkan dari segi desain dan orisinalitas. Jelas bahwa hipotesis diterima dalam penyelidikan ini.

Menurut hipotesis keempat, lokasi dan saluran distribusi memiliki dampak besar pada keputusan pembelian. Penelitian ini menegaskan bahwa lokasi/saluran distribusi memiliki dampak besar pada keputusan pembelian, yang konsisten dengan studi sebelumnya. (Tjahjono, 2013) dan (Setiawan, 2014) yang menyatakan bahwa Lokasi/Saluran distribusi berpengaruh signifikan terhadap keputusan pembelian. Jika lokasi/saluran distribusi UD Vira Jember ditingkatkan, maka akan semakin besar tingkat keputusan pembelian yang akan dilakukan pelanggan saat membeli atau berbelanja di UD Vira Jember nantinya. Jelas bahwa hipotesis diterima dalam penyelidikan ini.

Menurut hipotesis kelima item harga promosi dan marketing mix semuanya memiliki dampak simultan yang substansial pada pilihan pembelian. Studi ini menunjukkan bahwa produk, harga, promosi, dan lokasi / saluran distribusi (marketing mix) semuanya memiliki dampak besar pada pilihan pembelian pada saat yang sama, yang konsisten dengan studi sebelumnya yaitu (Ulus, 2013) dan (Firmansyah, 2015) yang menyatakan bahwa produk, harga, promosi, lokasi/saluran distribusi (marketing mix) berpengaruh secara simultan terhadap keputusan pembelian. Jika produk, harga, promosi, dan lokasi/distribusi (marketing mix) UD Vira Jember ditingkatkan, maka akan semakin besar pula jumlah keputusan pembelian yang akan diambil pelanggan saat membeli atau berbelanja di UD Vira Jember.

\section{Simpulan}

Produk berpengaruh positif dan signifikan terhadap keputusan pembelian, hasil temuan dari penelitian ini berarti semakin baik UD Vira Jember dalam memvariasi rasa produk atau macam-macam produknya maka akan semakin tinggi tingkat keputusan konsumen dalam membeli atau berbelanja pada UD Vira Jember.

Harga berpengaruh positif dan signifikan terhadap keputusan pembelian, hasil temuan dari penelitian ini berarti semakin baik UD Vira Jember dalam menawarkan maupun menetapkan harga maka akan semakin tinggi tingkat keputusan konsumen dalam membeli atau berbelanja pada UD Vira Jember.

Promosi berpengaruh positif dan signifikan terhadap keputusan pembelian, hasil temuan dari penelitian ini berarti semakin baik UD Vira Jember dalam meberikan pro- 
mosinya maka akan semakin tinggi tingkat keputusan konsumen dalam membeli atau berbelanja pada UD Vira Jember.

Lokasi/saluran distribusi berpengaruh positif dan signifikan terhadap keputusan pembelian, hasil temuan dari penelitian ini berarti semakin baik UD Vira Jember dalam menerapkan dan menetapkan lokasi maupun saluran distribusinya maka akan semakin tinggi tingkat keputusan konsumen dalam membeli atau berbelanja pada UD Vira Jember.

\section{Daftar Pustaka}

Budiwati, H., \& Masalah, L. B. (2012). Implementasi Marketing Mix Dan Pengaruhnya Terhadap. 2(2), 29-44. Balance, J. (2015). Jurnal Balance 28. Xii(2).

Ghozali, Imam. 2018, Aplikasi Multivarie Dengan Program Ibm Spss 21 Update Pls Regresi. Semarang : Badan Penerbit Universitas Diponegoro.

Hermawan, Haris (2015). Jurnal Manajemen Dan Bisnis Indonesia Vol. 1 No. 2 Desember 2015. 1(2), 143-161.

Kotler, Philip \& Garry Amstrong. (2009). Prinsip Prinsip Pemasaran Jilid 1 Dan 2 Edisi Kedua Belas, Jakaerta: Erlangga

Firmansyah, M. A., \& Mahardhika, B. W. (2015). Pengaruh Strategi Marketing Mix (Produk, Harga, Promosi Dan Distribusi) Terhadap Keputusan Pembelian Konsumen Batik Di Surabaya. BALANCE: Economic, Business, Management and Accounting Journal, 12(02).

Tantra, B., \& Marcelina, J. (2017). Pengaruh Marketing Mix (7P) Terhadap Keputusan Pembelihan Pada Guest House Di Surabaya. Jurnal Hospitality dan Manajemen Jasa, $5(2)$.

Setiawan, W. (2014). Pengaruh Marketing mix terhadap keputusan pembelian Toyota Avanza tipe G di Surabaya. Jurnal Strategi Pemasaran, 2(1), 1-8.

Sugiyono. (2008). "Metode Penelitian Kuantitatif Kualitatif \& Rnd". Bandung : Alfabeta Tjahjono, A., Semuel, P. H., Karina, R., Pemasaran, J. M., Petra, U. K., \& Siwalankerto, J. (2013). Analisa Marketing Mix , Lingkungan Sosial , Psikologi Online Pakaian Wanita. $1(2), 1-9$.

Ulus, A. A. (2013). Bauran Pemasaran Pengaruhnya Terhadap Keputusan Pembelian Mobil Daihatsu Pada PT. Astra Internasional Manado. Jurnal EMBA: Jurnal Riset Ekonomi, Manajemen, Bisnis dan Akuntansi, 1(4). 1134-1144.

Wulandari, Wahju. (2012). Jurnal Manajemen Dan Akuntansi Volume 1, Nomor 3, Desember 2012. 1, 45-63. 